\title{
The Study of the Entrepreneur's Values and Knowledge: Influence in Growth Expectations
}

\begin{abstract}
This study examines how entrepreneur's values and knowledge can influence growth expectations in new technology-ventures. The study analyses six Spanish cases with different level of growth expectations in their first years and with different characteristics in the entrepreneurial team. Our research reveals that entrepreneur's knowledge is not a factor that helps to differentiate the level of growth in this specific sector. However, we found certain values present in those new ventures with a higher growth expectations, mainly independence and wealth. The values that were not related are the need of exploitation and security. Finally, we draw a model to understand the relationship between entrepreneur's values and knowledge and their impact on new technology venture growth expectations.
\end{abstract}

Keywords: Knowledge; Values; New-Technology Venture; Growth Expectations

\section{Introduction}

The regional development as a result of entrepreneurship, is being driven mostly by technology (Mitra 2012). According to Alvarez and Marin (2013) the right combination of technological capabilities and external factors create competitive advantages for regions.

Corresponding author: a.campos@cucea.udg.mx

Received 08 October 2016 - Accepted 19 January 2017

This is an Open Access article distributed under the terms of the Creative Commons Attribution-Non-Commercial-No Derivatives License (http://creativecommons.org/licenses/by-nc-nd/4.0/), which permits non-comercial re-use and distribution, provided the original work is properly cited, and is not altered or transformed in any way. 
This is how new technology-based firms (NTBFs) play a key role on development and competitiveness of regions; (Audretsch 1995; Colombo and Grilli 2010).

This reason has led scholars to be interested in studying the main factors behind growth and success of this type of companies (Collombelli, Krafft and Quatraro 2012; Breznitz and Taylor 2014; Love and Roper 2015); in fact one of the most studied drivers of growth in academic literature is the role of the entrepreneur. Although growth is generally agreed as a good indicator of success and one of the aim of all the firms, not all the new ventures choose to grow (Edelman et al. 2010; Wiklund and Shepherd 2003).

In this sector, companies are created by a particular type of entrepreneurs, usually with very high levels of technical knowledge and skills. Sometimes it is even scholars and researchers who create spin-off companies (Prodan and Drnovsek 2010). In this line, some authors argue that technical entrepreneurs need a correct combination between technical and managerial skills in order to be able to exploit such expertise (Oakey 2003; Keil, Koo Lee and Deng 2013). When the company starts growing it is crucial that the founder has a support in finance, marketing and personnel areas (Oakey 2003). But, is really the managerial knowledge what can make the difference between a success and non-success technological entrepreneurs?

Usually, entrepreneurs in this sector possess high-technical training; in many cases come from university environments and they have been researchers for many years. In the case of Spain, many research centers and universities provide funding to researchers in order to turn the patents and innovations they are working with into real business projects. However, it is not unusual that these researchers had never thought about funding a company but they find this option the only way to continue developing their professional career. In this sense authors 
such as Elizur and Sagie (1999) or Evans, Carney and Wilkinson (2013) have highlighted the importance of the compatibility between life and work values.

Few researches have been found in terms of the role that personal values play when an entrepreneur set the growth expectations for new ventures.

Under these circumstances, the objective of this research is to analyze the influence of entrepreneur's personal values and knowledge in the growth expectations for new technologyventures. This influence will affect the way in which individuals manage their new technology-ventures and how knowledge and values influence the intention of growing. This research was carried out through the analysis of six different cases.

Following this introduction, the next section presents the theoretical framework and the propositions. The first theoretical chapter reflects on the role of entrepreneur's knowledge in the context of new technology ventures and in the next one, the role of entrepreneur's values is developed from a theoretical point of view. The methodology of the empirical study is then described. The main results obtained from the case study analysis are then presented. The study concludes with a summary of the main findings, implications, limitations and future research topics.

\section{Theoretical framework and research propositions}

Entrepreneur's knowledge in the context of new technology-ventures

Firms are considered by a great number of researchers, sets of resources systematically exploited and inter-related for producing and trading goods or services. For more than three decades now, scholars have explored firms and organizations' phenomena basing their 
researches on the analysis of resources (Wernerfelt 1984; Grant 1991; Conner and Prahalad 1996; Barney 2001; Lin and Wu 2014).

From the wide variety of resources and capabilities that give birth to a firm, knowledge is undoubtedly one of the most explored assets in academic literature. In the last years knowledge has been strongly related to the study of business creation and performance in several ways and nowadays there exist as much academic papers about this issue, as topics relating human beings and entrepreneurship.

Knowledge related topics in entrepreneurship have been studied at different levels (Campos and Hormiga 2010); the entrepreneurs' knowledge at the individual level (Dimov and Shepherd 2005; Arthurs and Busenitz 2006; Parker 2006, Roxas 2013), the group of entrepreneurs' knowledge level (Moreno-Luzon and Lloria 2008; West 2007; Friar and Mayer 2003; Watson et al. 2003; de Mol, Khapova, and Elfring 2015), the knowledge within the organization -organization level- (Deeds et al. 2000; Collinson, 2000; Corbett et al. 2007; Junkunc 2007; Sharder and Siegel 2007; Van Geenhuizen 2008; Palacios et al. 2009; Lyles 2014) and the inter-organization level referring to the knowledge flowing and being constructed amongst groups of organizations (O'Gorman and Kautonen 2004; Schildt et al. 2005; Biggeiro 2006). Particularly, the study of the entrepreneur's knowledge -at the individual level- is the dominant topic in academic literature of the field during the last decade. Individual level as the name implies, will refer to the creation or exploitation of all kinds of knowledge or sources of knowledge performed by an individual.

Undoubtedly, entrepreneur's knowledge has been a reference topic for researchers when measuring variables related to the performance and growth of nascent business. Most of the times factors of success and growth of new businesses have been strongly related to the 
possession, acquisition, development and implementation of entrepreneur's knowledge indicators such as skills, information, foreign languages domain and the most common knowledge indicators, education and experience (Almor and Lerner 2002; Kundu and Katz 2003; Williams and Chaston, 2004; Van Gelderen, Thurik, and Bosma 2005; Poon et al. 2006; Dutta and Thornhill 2008; West and Noel 2009).

As mentioned, education and experience have been the most commonly used entrepreneur's knowledge indicators for measuring their impact on new businesses development. Constantly these two indicators are found together as demographical variables affecting some other dependent variable of the firm (see table 1).

Table 1. Dependent variables measured taking education and experience as knowledge indicators

\begin{tabular}{|c|c|}
\hline Author & Dependent variable \\
\hline $\begin{array}{l}\text { Lin et al (2000); Arenius and Minniti (2005); De Clerq and Arenius (2006); } \\
\text { Kim et al (2006); Vinogradov and Kolvereid (2007); Thomas (2009); } \\
\text { Thompson et al (2010) }\end{array}$ & $\begin{array}{ll}\text { Self-employment } & \text { and } \\
\text { entrepreneurial activity } & \end{array}$ \\
\hline $\begin{array}{l}\text { Honig (2001); Watson et al (2003); Williams (2004); Lee and Osteryoung } \\
\text { (2004); Peña (2004); Ven Gelderen and Bosma (2005); Asterbro and Berhardt } \\
\text { (2005); Dimovand and Shepherd (2005); Van Gelderen et al (2005); Zartutskie } \\
\text { (2010) }\end{array}$ & $\begin{array}{l}\text { Profitability, success, } \\
\text { income and performance }\end{array}$ \\
\hline $\begin{array}{l}\text { Cowling and Taylor (2001); Ferrante (2005); Koellinger and Minniti (2006); } \\
\text { Ucbasaran et al (2008); Hyytinen and Ilmakunnas (2007); MacDonald et al } \\
\text { (2007); Backes and Werner (2007); Seawright et al (2008) }\end{array}$ & $\begin{array}{l}\text { Ability and attitudes to } \\
\text { create jobs, opportunity } \\
\text { identification, aspirations }\end{array}$ \\
\hline Nziramasanga and Lee (2001); Peña (2004); Marvel and Lumpkin (2007) & $\begin{array}{l}\begin{array}{l}\text { Duration of business, } \\
\text { innovation, } \\
\text { growth. }\end{array}\end{array}$ \\
\hline Hindle and Cutting (2002); Van Praag (2003); Chrisman and McMullan (2004) & $\begin{array}{l}\text { Job satisfaction, risks and } \\
\text { hazards, probability of } \\
\text { survival }\end{array}$ \\
\hline
\end{tabular}

Source: Own elaboration.

As stated, knowledge plays a critical role on business creation, existence and prevalence in the market; actually there are certain sectors where specialized knowledge determines the 
length and width in the life cycle of a new venture. Technology-based businesses require by nature greater and more specialized amounts of knowledge to be created and to be managed. In this sense we present the next research proposition:

Proposition 1a: The presence of high levels of technical knowledge implies high growth expectations in new technology ventures.

Besides all we have mentioned regarding the importance of technical knowledge in technology-based new firms, there has been a debate in academic literature about the real need for technological entrepreneurs of acquiring or not business management skills and if so, to what extent.

In this sense, Oakey (2003) argues that it is not the best choice that scientists entrepreneurs with strong technical expertise and that have succeed in the market so far, refuse to acquire management training in order to grow the business. This author considers important for entrepreneurs either to acquire this knowledge or even better, to hire or associate to someone who holds specialized business management skills, especially if financial assistance becomes an unavoidable need.

In high-technology sector, companies are mostly created by a particular type of entrepreneurs, usually with high levels of technical knowledge and skills. Sometimes it is even scholars and researchers who create spin-off companies (Prodan and Drnovsek 2010). In this line, Oakey (2003) argued that technical entrepreneurs need a correct combination between technical and managerial skills in order to be able to exploit such expertise. When the company starts growing it is crucial that the founder has a support in finance, marketing and personnel areas (Oakey 2003). But, is the managerial knowledge what can really make the difference between a success and non-success technological entrepreneurs? Trying to shed some light on this 
issue we present proposition $1 \mathrm{~b}$ as follows:

Proposition 1b: The presence of high levels of management knowledge implies high growth expectations in new technology ventures.

In order to understand in a deeper way this phenomenon, it is important to consider what lies behind it; it is crucial to consider the presence of many other factors that also influence the entrepreneur's desire to make his business grow and how to do it. This important decision relies not only on the amount and specialization of technical and/or managerial knowledge that the entrepreneurs possess, but also on the personal and individual characteristics that guide his/her motivational aspirations.

Entrepreneurs' values and new technology-ventures growth

There has been substantial investigation related to why individuals create a business (Cassar 2007). The motive that drives founders to develop business projects can either mean added value for the firm or have a negative effect on it. Various authors have studied the influence of motivations on the subsequent success of the firm and on organisational processes (Gatewood et al. 1995; Van Praag 2003; Van Praag and Cramer 2001; Peña 2002; CollinsDodd et al. 2004). Most of those authors draw the conclusion that the fact the owner is driven by intrinsic motivation -putting a personal idea into practice-, or by the need to be his/her own boss is an asset for the firm, which will have greater chances of surviving and obtaining future utilities than if he/she is driven by the impossibility of finding a job.

The characteristics of the market in which high technology firms operate may influence the specific motivational tendencies (Oakey 2003). Oakey (2003) found that there were three major motives for beginning a new technology business: independence, wealth and exploitation; the desire for independence is divided into two, freedom and control. In this 
sense, the frequently noted strong desire for control among many founders may negatively influence the capacity of growing or even lead to the death of the firm. This necessity can be higher in this sector in which knowledge properties are enormously important and where many competitive advantages are based on technical specific knowledge. Cassar (2007) found that the need of independence of the entrepreneurs was not a motivation that helps firms to grow; but does this value influence the growth expectation of founders?

The other group of motivations is the one based on wealth. Cassar (2007) found that financial success motivation was a key determinant for new venture's growth. This results were contradictory to some others studies that suggest that non-economic concerns were more important that financial outcomes in determinants of entrepreneur attitudes and expectations of growth (Amit et al. 2000; Wiklund et al. 2003), after all in this sector, the necessity of exploitation is one of the founders' values commonly identified. Most of the entrepreneurs in this sector have very high levels of technical knowledge and discover new ways of doing and improving their environments. Because of the characteristics of the products or services, the need to exploit this opportunity and communicate to society these technological advances moves many of these individuals in a higher rate than in other sectors.

There are many theories that have tried to explain the motivational process. Theories focused on expectancy for success, theories focused on task value or theories that integrate expectancies and values (Eccles and Wigfield 2002). In the last group of theories we found a modern expectancy value theory which both these components - expectancy and value- are more related to social/cultural determinants and positively related to each other (Feather 1988; 1995). Feather's work on values is an extended of Atkinson's original expectancy-value model in important ways by broadening the conceptualization of value. He argued that values 
are one class of motives that lead individuals to perform acts they think should be done (Feather 1995). This author assumes that values function like needs to influence goal directed behaviour and can influence the choices that are made between alternative activities and the way situations are constructed.

Trying to shed some light on this issue we focus on a topic that has been usually related to work in academic business research: values. Rokeach $(1973,5)$ defines values as "an enduring belief that a specific mode of conduct or end-state of existence is personally or socially preferable to an opposite or converse mode or conduct or end-state of existence". García and Dolan $(2003,63)$ assume that value is a "strategic learning relatively stable about a way of acting is better than the opposite to obtain our goals or to make the things go well". Depending on the level of analysis we can find different levels such as (Roe and Ester 1999): country, group, and individual. Cultural values represent the implicitly or explicitly shared abstract ideas about what is good, right, and desirable in a society (Williams 1970). Although culture values will influence individual values, in this research we will focus on the individual level, specifically in the figure of the entrepreneur.

Before that, it is important to understand which the precedence of these values is and how they influence in the behaviors. The beliefs are structures of thinking, developed through a learning process that helps individuals to explain the reality. The attitudes are consequences of the values and are tendencies to evaluate, positively or negatively, a person, thing or fact. The attitudes predict our tendency to act in a specific way (García and Dolan 2003). In this sense, to modify behaviors it is necessary to change beliefs and values more than only the attitudes (García and Dolan 2003). 
Figure 1. Sequence between beliefs and results

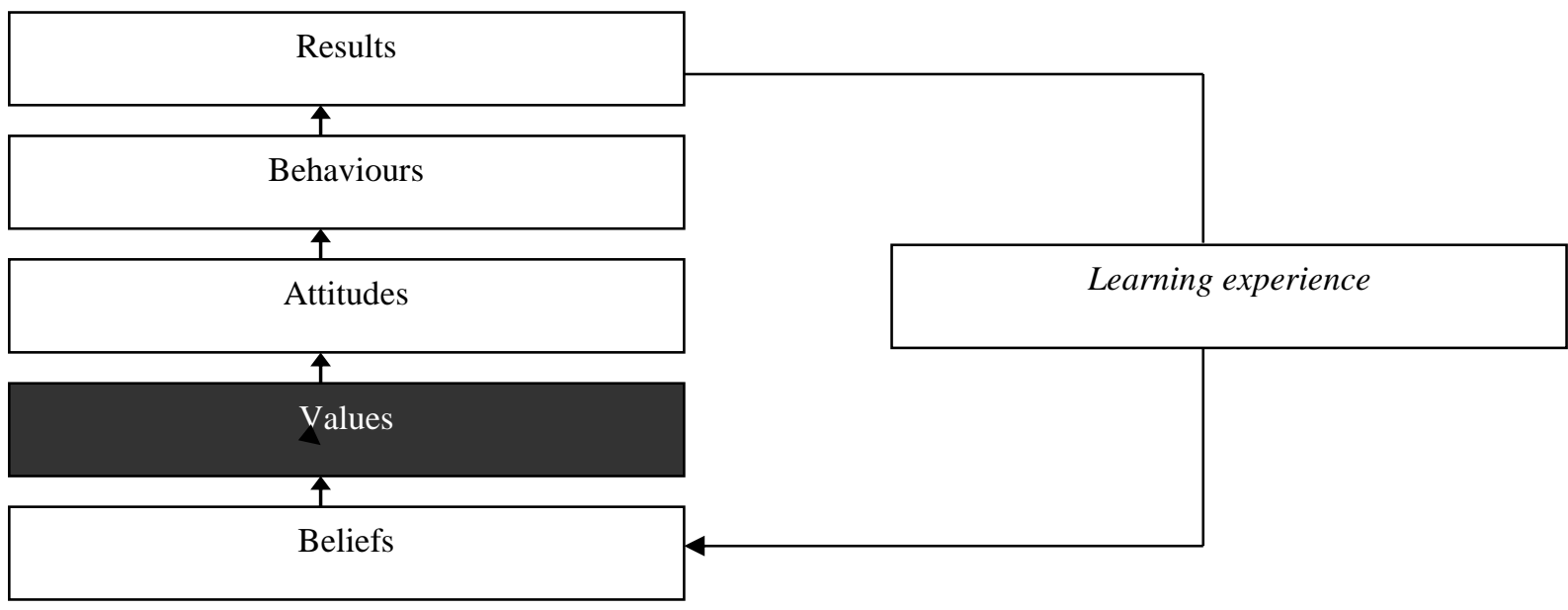

Source: Adapted from García and Dolan $(2003,72)$

Rokeach (1973) divided values into two sets: terminal and instrumental. Terminal values are existential objectives, which are end states of existence or ultimate modes of living, what has been idealized as "good life". Instrumental values are those values that represent the way of acting necessary to get the existential values.

There are some personal values that it is quite clear what kind of behaviors or situations they are relevant to (e.g. money or good friends), but there are other values a little more diffuse such as meaningful life or work (Elizur and Sagie 1999). Traditionally, general life values and work values have been investigated independently (Elizur and Sagie, 1999; Roe and Ester 1999) but most researchers seem to assume that work values do somehow derive from general values even though they are not very explicit about the causal nature of this process. In some cultures, work values could be a source from which general values arise, for example multinational corporations can play a role in the transmission of values but this is an approach with little empirical evidence (Schwartz 1999).

In this research, we focus on those values that can influence in new ventures' growth 
expectations -see figure 2-. First referring to terminal values, the importance and significance of work in a person's life will be crucial for the entrepreneurs' and for new venture management as well as for the growth expectations.

Since most of the times the initial stage of the firm lacks of stability, routines and processes are not formally established and it is necessary for the entrepreneur to be completely involved to overcome that deficiency. A high level of personal commitment by the entrepreneur contributes added value to the firm and may mark the difference between some entrepreneurial initiatives and others (Timmons 1990). According to this, authors such as Cooper et al. (1994) state that greater commitment from the entrepreneur has a decisive influence on the survival of the firm. Other authors like Peña (2002) and Collins-Dood et al. (2004) state that there is a positive relation between the level of founder's dedication to the business and the level of success of the business and those founders with higher expectations of growth will present higher levels of commitment to the company. Therefore, hard work as well as strong commitment has been highlighted as important elements for the smooth running of newly-created firms (Rodríguez 2003). Schwartz (1999) compares the importance of work relative to four other life areas - leisure, community, religion and family. We propose that a greater importance the individual gives to work lead to greater expectations of growth and greater opportunities to devote his efforts to be successful.

Proposition 2: The presence of entrepreneur's terminal value "centrality of work" is related to high levels of growth expectations in new technology ventures.

Instrumental values are divided into moral and competences values and competence values (Rokeach 1973). Moral values have two particular characteristics: they are related to other people and when there are no-connection between values and behavior they cause feelings of 
guilt and shame (García and Dolan 2003). The competence values are more individualistic and they have no direct relation to culpability and moral feelings. For example, honesty implies a feeling that you are acting morally while creativity implies that you are acting according to a competence. In our analysis we focus on these values -competences- that can influence the growth expectations of new ventures -independence, exploitation, sacrifice, security, stability and wealth-.

Figure 2. Entrepreneur's values that influence new venture growth

\begin{tabular}{|c|c|}
\hline Individual values that influence new venture growth \\
\hline Centrality of work respect to other terminal values: \\
Leisure \\
Community \\
Feligion
\end{tabular}

Source: Own elaboration.

This study tries to understand how knowledge and values of new technology-ventures' founders are related to their growth expectations and why the entrepreneur is willing to grow or not.

Based on previous assumptions we proposed the following propositions:

Proposition 3a: The presence of entrepreneur's instrumental value "independence" is related to high levels of growth expectations in new technology ventures.

Proposition 3b: The presence of entrepreneur's instrumental value "sacrifice" is related to high levels of growth expectations in new technology ventures. 
Proposition 3c: The presence of entrepreneur's instrumental value "wealth" is related to high levels of growth expectations in new technology ventures.

Proposition 3d: The presence of entrepreneur's instrumental value "exploitation" is not related to high levels of growth expectations in new technology ventures.

Proposition 3e: The presence of entrepreneur's instrumental value "security" is not related to high levels of growth expectations in new technology ventures.

Proposition 3f: The presence of entrepreneur's instrumental value "stability" is not related to high levels of growth expectations in new technology ventures.

\section{Method}

Research design

According to several qualitative methodologists multiple case-based research may serve as a basis for either empirically testing previous theories or building new theoretical explanation of the phenomenon being researched (Eisenhardt 1989; Yin 1989; 1998).

To achieve the objectives of the research we followed a qualitative methodology -case study(Yin 1989; Eisenhart 1989), following different steps. First, the theoretical framework of the research was developed from a literature review. Second, we use this framework as guide to organize our data collection and to analyze them. In this sense, the relationship between the theoretical perspective and the empirical findings is very close (Yin 1989). To obtain the data we used primary and secondary sources. Through the performance of deep interviews we gathered information related to their knowledge and personal values and how these two factors were affecting the management of the new venture.

By adopting the founder/s as the main unit of analysis, our empirical research is based upon a systematic application of the multiple-holistic case study approach to new technology context 
in which six new ventures created in Catalonia (Spain) were first judgmentally -not randomly- chosen and then comparatively examined. This conceptual sampling design allowed us to introduce some degree of variance in our case selection criteria by including differences in entrepreneur's gender and origin and individual entrepreneurs versus entrepreneurial teams. However, to be consistent with previous research on entrepreneurial firms which are regarded as typically young and small in size (Zacharakis 1997), all firms in the purposeful sample had to be small, and independently managed.

Case selection and data collecting

Six cases were selected to make a deep analysis of the entrepreneur/s leading these new technology ventures. The six entrepreneurial stories for this study were selected in order to make a deep analysis of the entrepreneur/s leading these new technology ventures. These companies were selected based on the number, sex and the nationality of the founders. Specifically, some characteristics of the entrepreneurs in this study are the following:

- Three of them are entrepreneurial teams and three are individual founders.

- Two companies have female components in the entrepreneurial team and four are male teams.

- Two companies have at least one immigrant member in the entrepreneurial team and four were native teams.

Initial contact with these companies was made by telephone. During the initial telephone discussion with at least one of the founders, the aims and objectives of the case study were outlined. Also our requirements about who should be interviewed and the approximate duration of the interview were explained. Some of the company's founders were concerned 
about confidentiality issues, while other founders had no problems to talk about their personal stories. The interest to use the case study for publication was also revealed at the first contact. Our data collection consisted on deep personal interviews conducted using semi-structured questionnaires as a guide. As mentioned, the interview content was drawn from literature and also guided by previous studies.

The interviews included questions about general characteristics of the company and the founder's characteristics.

Table 2. Interview structure

\begin{tabular}{ll}
\hline General structure & Discussion topics \\
\hline General characteristics & Company's features \\
\hline & Entrepreneur's features \\
\hline Knowledge & Education \\
& Experience \\
& Type of knowledge \\
\hline Personal values & Perception of knowledge \\
\hline Growth expectations & Terminal values \\
\hline
\end{tabular}

Source: own elaboration.

During the visit to the companies, extended interviews were conducted with at least one of the founders of each company. Each case company lasted approximately 2 hours. In addition to the interviews, we used secondary sources to verify the statements and to obtain supplementary information. The information gathered from each organisation was written up as a case study and the principal observations extracted.

Firm and interviewees characteristics

As explained above, the data explained in this article refers to six technology-ventures. Table 3 presents a profile of these cases. The sample is composed of companies with some diversity 
within the industry although most of them correspond to young sectors: IC technologies and biotechnology.

According to European Commission Recommendation (2003/361/EC), in terms of headcounts as main criterion, three companies $(3,5$ and 6$)$ were micro enterprises, employing fewer than ten people, whereas the other three (1,2 and 4) belonged to the small enterprises category.

Table 3. Sample profile

\begin{tabular}{|c|l|c|r|}
\hline Cases & \multicolumn{1}{|c|}{ Economic sector } & No employees & Annual sales $(\boldsymbol{\epsilon})$ \\
\hline 1 & Biotechnology & 16 & 900,000 \\
\hline 2 & IC Technologies & 27 & $1,000,000$ \\
\hline 3 & Environmental technology & 2 & 0 \\
\hline 4 & IC Technologies & 14 & $3,600,000$ \\
\hline 5 & Biotechnology & 6 & 510,000 \\
\hline 6 & Biotechnology & 4 & 170,000 \\
\hline
\end{tabular}

Source: own elaboration.

In table 4 we present our findings relating the characteristics of the new technology-ventures' founders. The management of the firm consisted of a small team although in same cases only one of the founders took this role. Only one out of six companies had a single female founder.

Table 4. New technology-ventures' founders characteristics

\begin{tabular}{|l|l|l|c|l|}
\hline Cases & \multicolumn{1}{|c|}{ Gender } & \multicolumn{1}{c|}{ Nationality } & No founders & \multicolumn{1}{c|}{ Previous position } \\
\hline 1 & Males & Spanish & 2 & Students \\
\hline 2 & Female & Spanish & 1 & Skilled worker \\
\hline 3 & Males & Argentinean & 2 & Skilled workers \\
\hline 4 & Males & Spanish & 2 & Skilled worker / Professor \\
\hline 5 & Female/ Male & Spanish & 2 & Skilled worker \\
\hline 6 & Male & Italian & 3 & Student / Professors \\
\hline
\end{tabular}

Source: own elaboration.

Regarding the nationality of the teams, four of them were formed only by Spanish people and two by an immigrant founder, which co-founded the company with native people. Finally, concerning the previous position of the founders, we found that most of them were skilled 
workers in other companies, only in case one the company was founded by students without professional experience and two companies had at least one university professor involved.

In this study the units of analysis are founders of high-technology based companies that have received any support from a specific public institution from Catalonia.

\section{Findings and discussion}

Knowledge

Regarding founders' knowledge we found differences amongst the profiles of interviewees; even if all of them hold technical graduate degrees in at least one field close to the main company's core business there are some of them that also have completed some businessrelated graduate program, some others just have attended certain management courses and one of them hold on to experience as the only source of management knowledge (see table 5)

Table 5. Founders' knowledge

\begin{tabular}{|l|l|c|c|c|c|c|c|}
\hline $\begin{array}{l}\text { Type of } \\
\text { knowledge }\end{array}$ & Cases identified & $\mathbf{1}$ & $\mathbf{2}$ & $\mathbf{3}$ & $\mathbf{4}$ & $\mathbf{5}$ & $\mathbf{6}$ \\
\hline Informal & Experience & $\mathrm{x}$ & & & $\mathrm{x}$ & & $\mathrm{x}$ \\
\hline \multirow{3}{*}{ Formal } & $\begin{array}{l}\text { High technical } \\
\text { knowledge, PhD }\end{array}$ & $\mathrm{x}$ & & $\mathrm{x}$ & $\mathrm{x}$ & $\mathrm{x}$ & $\mathrm{x}$ \\
\cline { 2 - 9 } & Management courses & & & $\mathrm{x}$ & & $\mathrm{x}$ & \\
\cline { 2 - 9 } & MBA & $\mathrm{x}$ & $\mathrm{x}$ & & $\mathrm{x}$ & & \\
\hline
\end{tabular}

Source: Own elaboration

If we look at entrepreneurs' informal knowledge, we found that cases number 1, 4 and 6 , have some previous experience in managing business either if this experience come from business in the same sector or not. In these cases $-1,4$ and 6- we found some evidence of the contribution of their informal knowledge to management skills and intentions of growing. As an illustrative example of one of these experienced founders, in case 1 founder reveals that he has been in contact with successful entrepreneurs and since childhood he used to listen to 
conversations among them; he admitted: "I've been my whole life preparing myself to be an entrepreneur".

Concerning formal knowledge of the entrepreneurial teams, there are many different situations. In the sample, only case 2 does not have technical education at a higher level than undergraduate, while others have at least one of the members holding a doctoral degree, being university professors or even persons awarded with international academic prizes. We also found that in the four companies -1, 2, 4 and 5- that stated to have strong intentions to growth at least one of the founder members has some type of management knowledge either acquired through formal higher education or through the attendance of some management courses (see figures 3.1, 3.2, 3.4 and 3.5)

On the other hand, high technical knowledge characteristic does not imply the existence of growth intentions; case number 2 shows a strong intention to grow even without higher levels of technical education.

According to data collected, case 6 is the only one that supplies the lack of managerial skills with the incorporation of another company in the company's capital that contributes with funding and with management advice. The owner of this company does not state intentions to grow; he reveals to be happy with the actual situation of the company; not closed to some minimum growth in the future though (see table 5).

It is worth to mention that all of them agreed that their knowledge at the beginning of company's life was not enough to manage it, although most of them recognized that only experience provides the right scope to complement other formal learning like courses or master degrees. 
Individual values

Individual values are other factors that affect entrepreneurial activity and we have analyzed the influence of these values on the way individuals manage their companies and the intention of growing. We took into account both terminal and instrumental values and these were the results of each case analysis:

Table 6. Individual values

\begin{tabular}{|l|l|c|c|c|c|c|c|}
\hline $\begin{array}{l}\text { Individual } \\
\text { values }\end{array}$ & Cases identified & $\mathbf{1}$ & $\mathbf{2}$ & $\mathbf{3}$ & $\mathbf{4}$ & $\mathbf{5}$ & $\mathbf{6}$ \\
\hline Terminal values & Strong centrality of work & $\mathrm{x}$ & & $\mathrm{x}$ & $\mathrm{x}$ & & $\mathrm{x}$ \\
\hline \multirow{4}{*}{$\begin{array}{l}\text { Instrumental } \\
\text { values }\end{array}$} & Willingness to sacrificing & $\mathrm{x}$ & & $\mathrm{x}$ & $\mathrm{x}$ & & $\mathrm{x}$ \\
\cline { 2 - 8 } & Security & & $\mathrm{x}$ & $\mathrm{x}$ & & & \\
\cline { 2 - 8 } & Stability & & $\mathrm{x}$ & & & $\mathrm{x}$ & $\mathrm{x}$ \\
\cline { 2 - 8 } & Independence & $\mathrm{x}$ & & & $\mathrm{x}$ & $\mathrm{x}$ & \\
\cline { 2 - 8 } & Wealth & & & $\mathrm{x}$ & & & $\mathrm{x}$ \\
\cline { 2 - 7 } & Exploitation & & & & \\
\hline
\end{tabular}

Source: Own elaboration

Regarding terminal values, most of the founders positioned work as the main priority in their spending-time-in list. Only in cases 2 and 5 founders consider job as a mean to enjoy life, but family, friends and health were priority. By contrast, cases 1, 3, 4 and 6 have committed their life to work and have renounced to many aspects of their life, although one of the founders in cases 3 and stated that they would like to reduce the importance of work as soon as the company’s situation make it possible.

Sacrifice, security, stability, independence, wealth and the ethical need of exploitation were the instrumental values we analyzed for each one of our cases. Half of the cases $(2,5$ and 6$)$ looked for stability when they became entrepreneurs, as they perceive that there is more risk of loosing their jobs if they work in a multinational or someone else's company; although surprisingly only case 6 also recognized the scarify made for starting-up the company; cases 2 and 5 do not find this strictly necessary due to a proper management of the company. 
Moreover, we found a relationship between those cases with high levels of sacrifice and without looking for security, stability or ability to earn money, and companies that grew up and have higher future growth expectation. The following quotes of a founder in case 1 is illustrative:

"We renounced to youth"

"I haven't stepped on a discotheque since I was 24"

Independence as an instrumental value is factor for creating the new technology-ventures in half of the cases (2, 4 and 5). The sensation of freedom and not depending on other's businesses or research lines is really important for some of the entrepreneurs. Those founders with this need for freedom presented higher growth expectations (see figures 3.2, 3.4 and 3.5). Some comments illustrate perfectly how this instrumental value had significant influence on founding the company:

\section{"I want things to depend on myself" \\ "You are the master of your destiny"}

But if we look at founders with terminal values more related to wealth (cases 1 and 6), we notice that there are different personal objectives. Case 1 likes generating business and get earnings for it; in this case growth expectation is strong (see figure 3.1); founder in case 6 needs a job with intellectual stimulation however, growth expectations in this case don't go further than survival or perhaps a minimum future growth (see table 6).

Finally, only case 3 showed a strong need of exploiting his knowledge (see figure 3.3). This founder gave up the academic field to investigate "practical things", although this is the case with the worst business performance. He defines himself as "an inventor with an ethical goal of sustainability" and wants his invents to be used. 


\section{Growth expectations}

Comparing the situation of the six cases, we do not find clear differences between the way they manage their companies or even their growing expectations. Only case number 3 recognizes the willingness to sell out the company if the technology developed is used; this shows a greater interest in survival in the meantime waiting for a good offer. Case 6 recognized not having special interest on growing a big company as long as he achieves to market their products.

When we asked the interviewees about their vision of the company 5 years in the future they showed different levels of growth expectations:

Table 6. Growth expectations

\begin{tabular}{|l|l|}
\hline Case & Growth expectations \\
\hline 1 & "Unlimited growth expectations" \\
\hline 2 & $\begin{array}{l}\text { "A bigger company, but with a higher role of the management team and more free } \\
\text { time for me" }\end{array}$ \\
\hline 3 & "I may sell the company if my technology is used" \\
\hline 4 & $\begin{array}{l}\text { "A big company with international reputation. We want to do something great, } \\
\text { with great people!" }\end{array}$ \\
\hline 5 & $\begin{array}{l}\text { "A company with } 60-70 \text { employees, in London. If someone wants to buy it, we'd } \\
\text { sell it and start another business" }\end{array}$ \\
\hline 6 & $\begin{array}{l}\text { "A company just slightly bigger than now to earn some more money, but I'm } \\
\text { happy with the actual situation anyway" }\end{array}$ \\
\hline
\end{tabular}

Source: Own elaboration.

In cases 1, 2 and 4 founders have the highest growth expectations, and we check that these three companies have had a very successful activity. Specifically, in cases 1 and 4 one of the founders has strong managerial skills and experience; these founders have "business spirit" and have always wanted to be entrepreneurs. Nevertheless, the other founders in 1,2 and 4 had never thought about being entrepreneurs as a career choice and they expect to have more leisure time, but they were encouraged to start the business by their co-founder or partner. 
Concerning cases 3 and 5, we found that founders are willing to sell out the companies, however case number 5 have clear intentions to grow before that while case 3 would sell the company as soon as their technology is used and they receive a good offer.

Before presenting final remarks of this work, we present next a brief individual analysis for each case:

Figure 3.1. Influence of entrepreneurs' knowledge and values in growth expectation -Case 1.
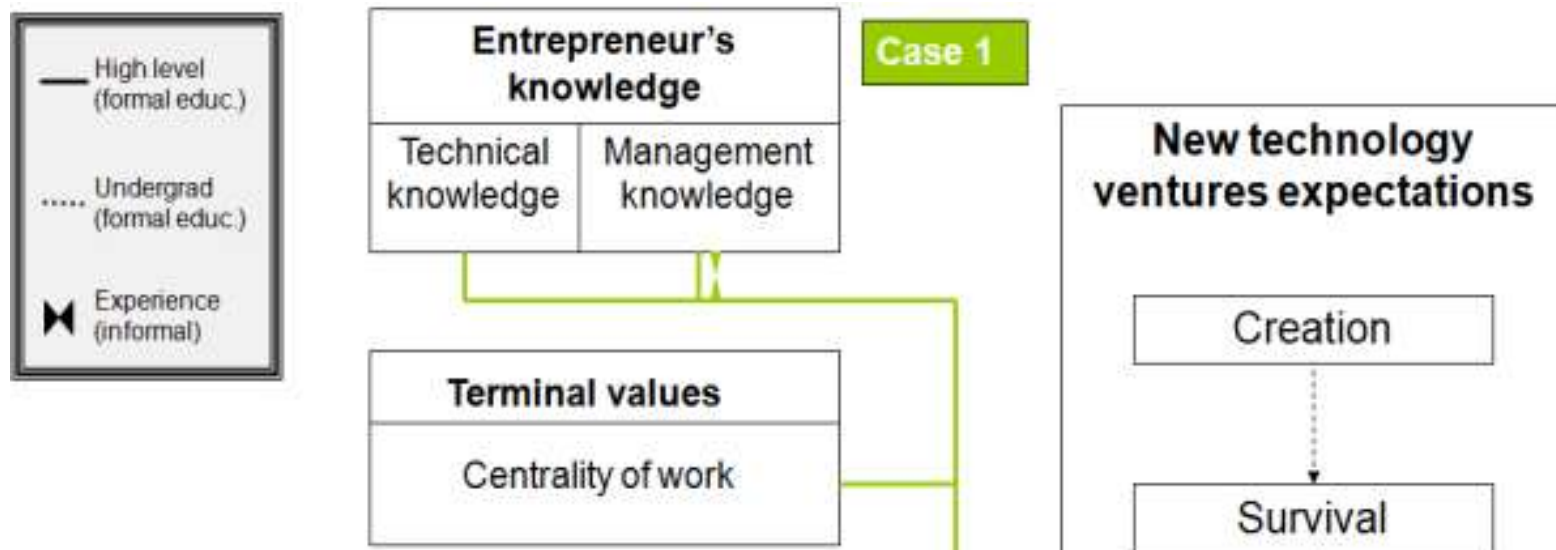

\begin{tabular}{|c|}
\hline Instrumental values \\
\hline Independence \\
\hline Exploitation \\
\hline Sacrifice \\
\hline Security \\
\hline Stability \\
\hline Wealth \\
\hline
\end{tabular}

Source: own elaboration.

In case one we find that founder(s) possess high levels of both technical and managerial formal knowledge as well as experience. Centrality of work is strong and company looks for wealth and the highest growth expectations of the sample are identified. 
Figure 3.2. Influence of entrepreneurs' knowledge and values in growth expectation -Case 2.
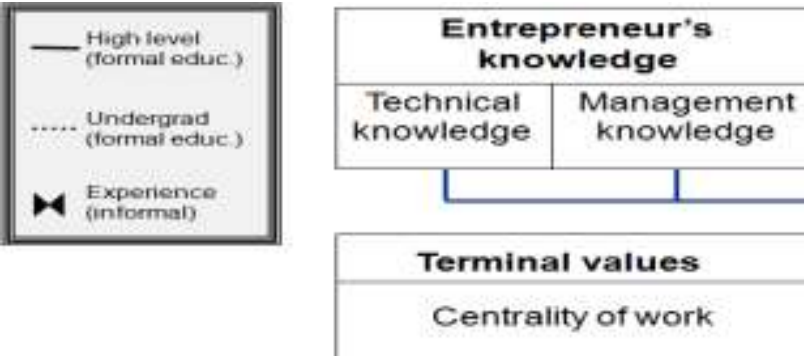

\section{Case 2}

New technology

ventures expectations

\begin{tabular}{|c|}
\hline Instrumental values \\
\hline Independence \\
\hline Exploitation \\
\hline Sacrifice \\
\hline Security \\
\hline Stability \\
\hline Wealth \\
\hline
\end{tabular}

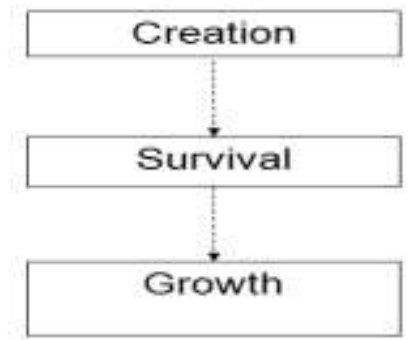

Source: own elaboration.

In case two we find that founder(s) possess undergraduate level technical formation and high levels of managerial formal knowledge. Independence, security and stability are the most important instrumental values for this company; even though this company seeks for growth, they consider family, friends and own life more important than business among their priorities.

Figure 3.3. Influence of entrepreneurs' knowledge and values in growth expectation -Case 3.
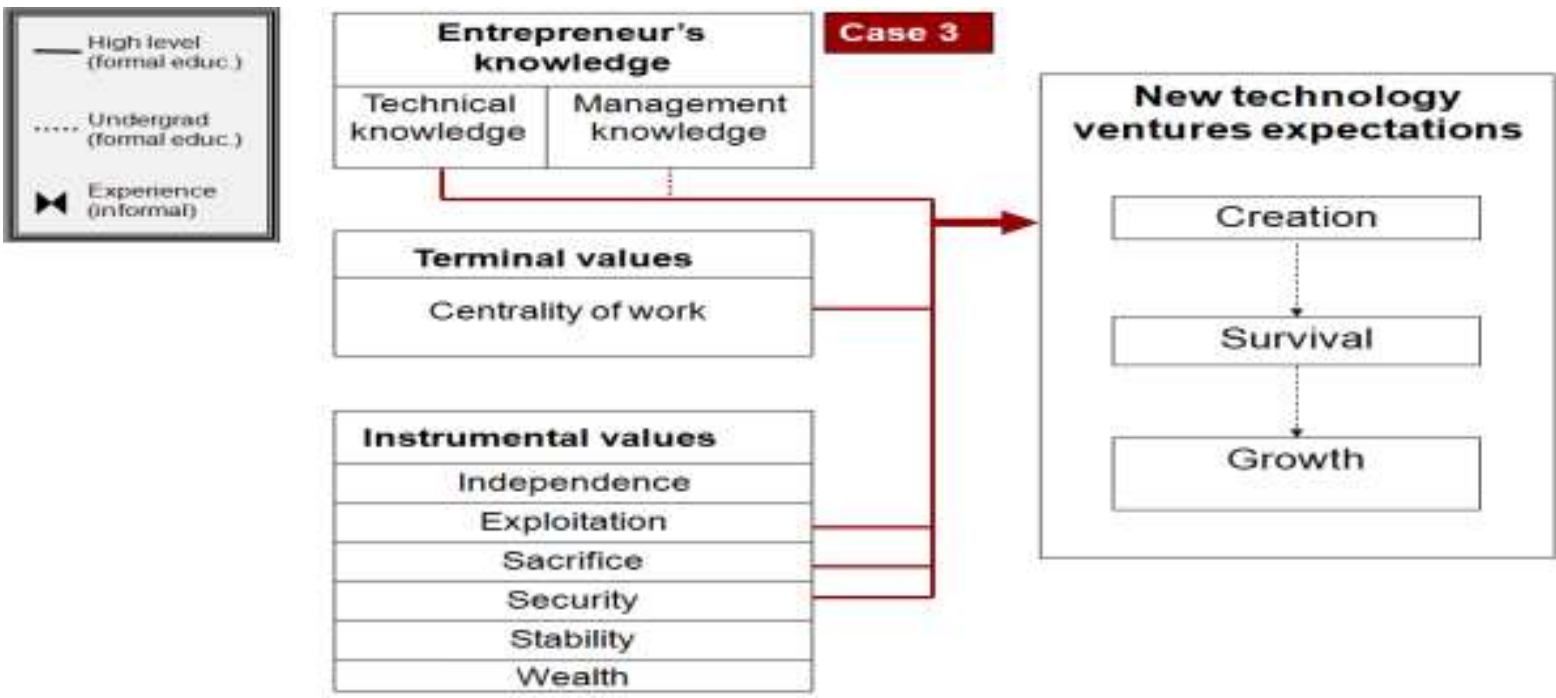

Source: own elaboration 
Case three shows that founder(s) possess high levels of technical knowledge and basic levels of managerial knowledge acquired by course or seminars attendance. Work is the priority for founder(s), they are eager to sacrifice free time and other activities for the company, they feel secure of what they do and feel the major need of exploiting their expertise in the field. They are willing to sell out the company as soon as the technology developed is used and receive a good offer. Growing is not a priority for them.

Figure 3.4. Influence of entrepreneurs' knowledge and values in growth expectation -Case 4.

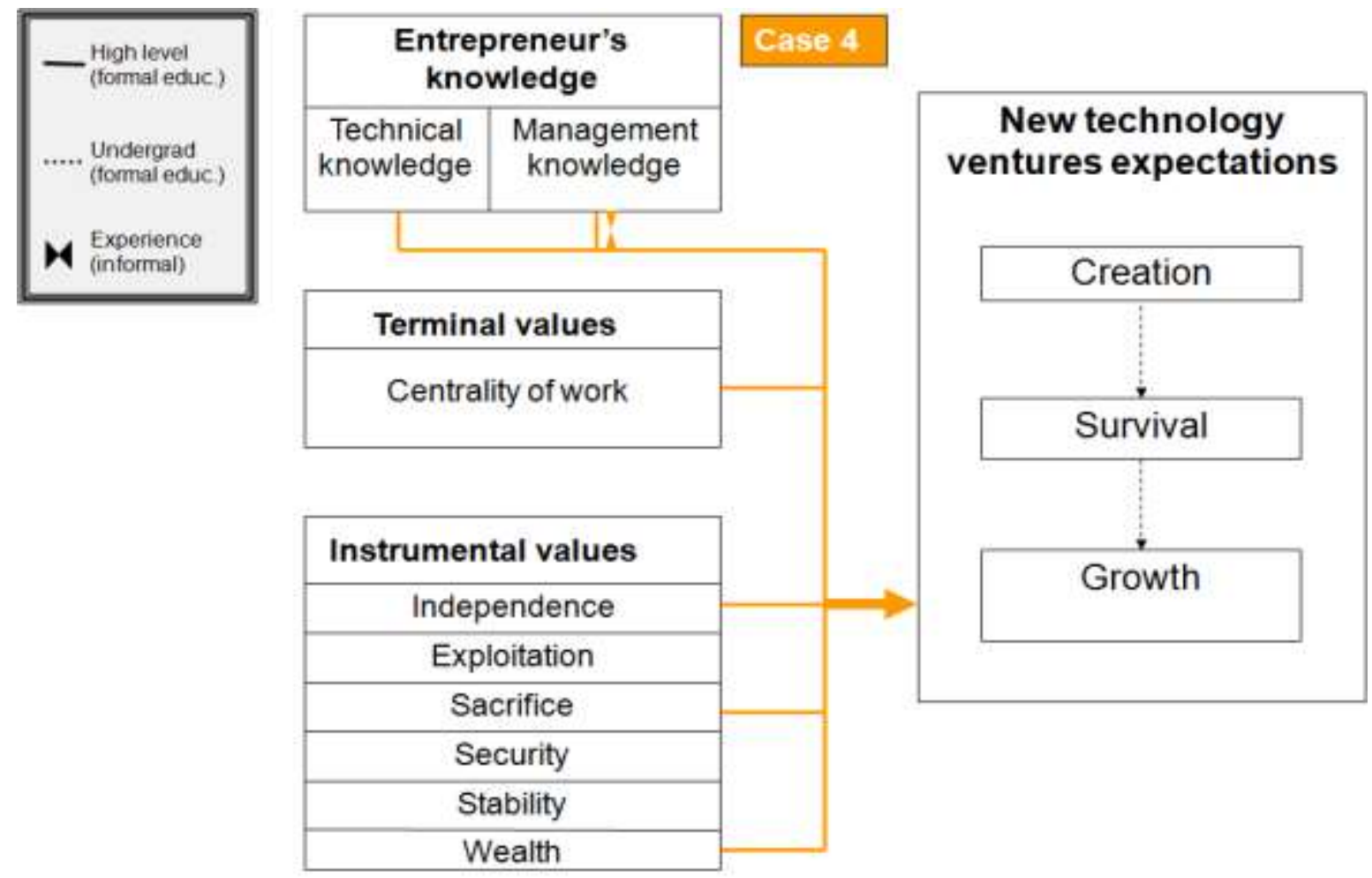

Source: own elaboration.

In this case -number 4- we find that founder(s) possess high levels of both technical and managerial formal knowledge as well as experience. Centrality of work is strong and company looks for wealth; founder(s) want to be independent and they are eager to sacrifice other activities to work and produce more richness; growth expectations are high. 
Figure 3.5. Influence of entrepreneurs' knowledge and values in growth expectation -Case 5 .
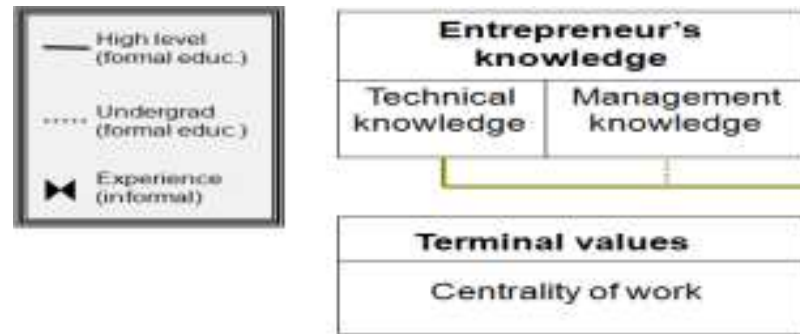

\begin{tabular}{|c|}
\hline Instrumental values \\
\hline Independence \\
\hline Exploitation \\
\hline Sacrifice \\
\hline Security \\
\hline Stability \\
\hline Wealth \\
\hline
\end{tabular}

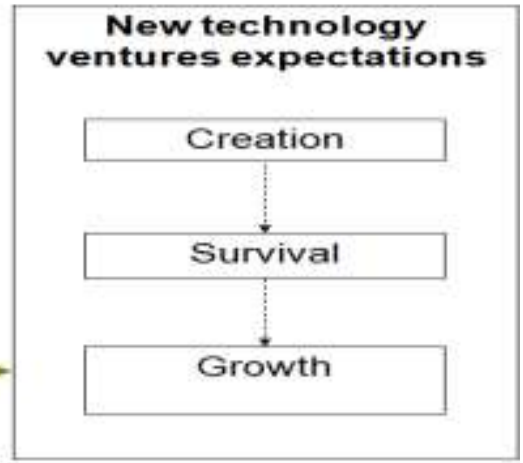

Source: own elaboration.

Case number five shows that founder(s) possess high levels of technical knowledge and basic levels of managerial knowledge acquired by course or seminars attendance. Work is important for founder(s) but not as much as family, friends or personal interests; personal stability is very important for them; they have a clear idea of growing and if there's a good offer, they wouldn't hesitate in selling out the company to start a new one.

Figure 3.6. Influence of entrepreneurs' knowledge and values in growth expectation -Case 6.
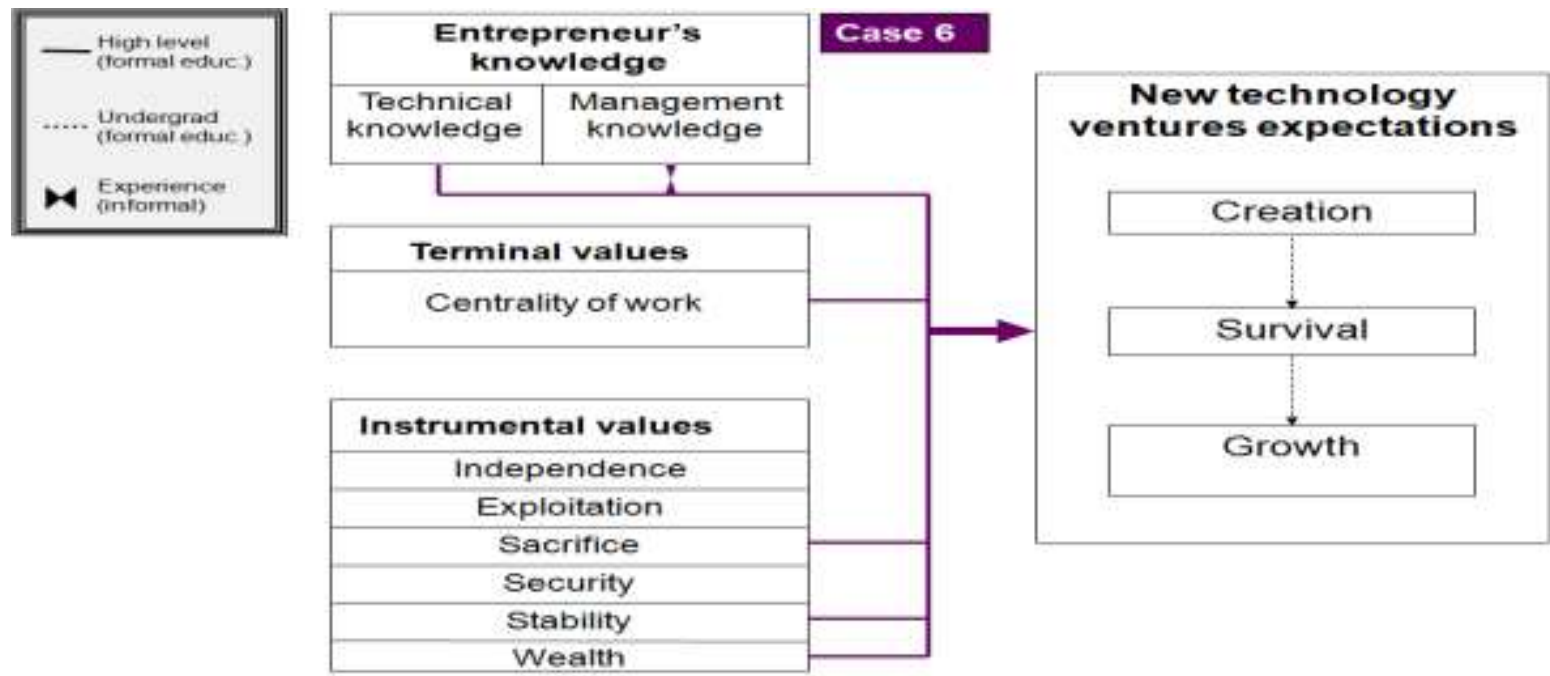

Source: own elaboration. 
Last case -number 6- shows that founders have high levels of technical knowledge and some managerial experience. They are committed to work seeking for stability and richness, they sacrifice personal activities for the company and don't have high expectations for growth; they seem to be happy with what the company is at the moment.

\section{Conclusions, implications and limitations}

After analyzing the six cases we could extract some conclusions.

First, in all the cases at least one of the entrepreneurs had never thought about being entrepreneurs as a career choice. Those entrepreneurs that have partners with "business" spirit had a very successful company performance and high growth expectations. However, those entrepreneurs with brilliant technical knowledge but no managerial skills did not perform well even if they tried to fulfill this lack of managerial knowledge joining well recognized management masters or courses. Curiously these entrepreneurs were pretty much alone or their partners were "technical". These entrepreneurs argued that what they really liked in their job was "discovering new things" or "see the impact of their new technologies on the environment" but they had been forced to receive training and learn management basics to keep doing what they like.

While performing the analysis of the cases we could identify some of their personal values such as security or money related values struggling with some other values considered important to develop an entrepreneurial activity.

Centrality of work is a terminal personal value that allocates work over any other activity in terms of importance and commitment on behalf of the entrepreneurs. This value according to the analysis is strongly related to higher levels of growth expectation. In terms of instrumental values we recognize that the seeking for wealth and independence are the most related to a 
high expectation of company's growth, while de feeling of security and the ethical need for exploiting certain expertise presents lower levels of relatedness to growth intentions (see figure 5).

Three out of the four cases that presented higher levels of growth intention, were founded by entrepreneurs with high levels of technical knowledge and the other one just professional level of this knowledge; however in all of these cases exists managerial knowledge in one of the founders (see figure 4).

Figure 4. Overall impact of knowledge and individual values in new technology-business expectations

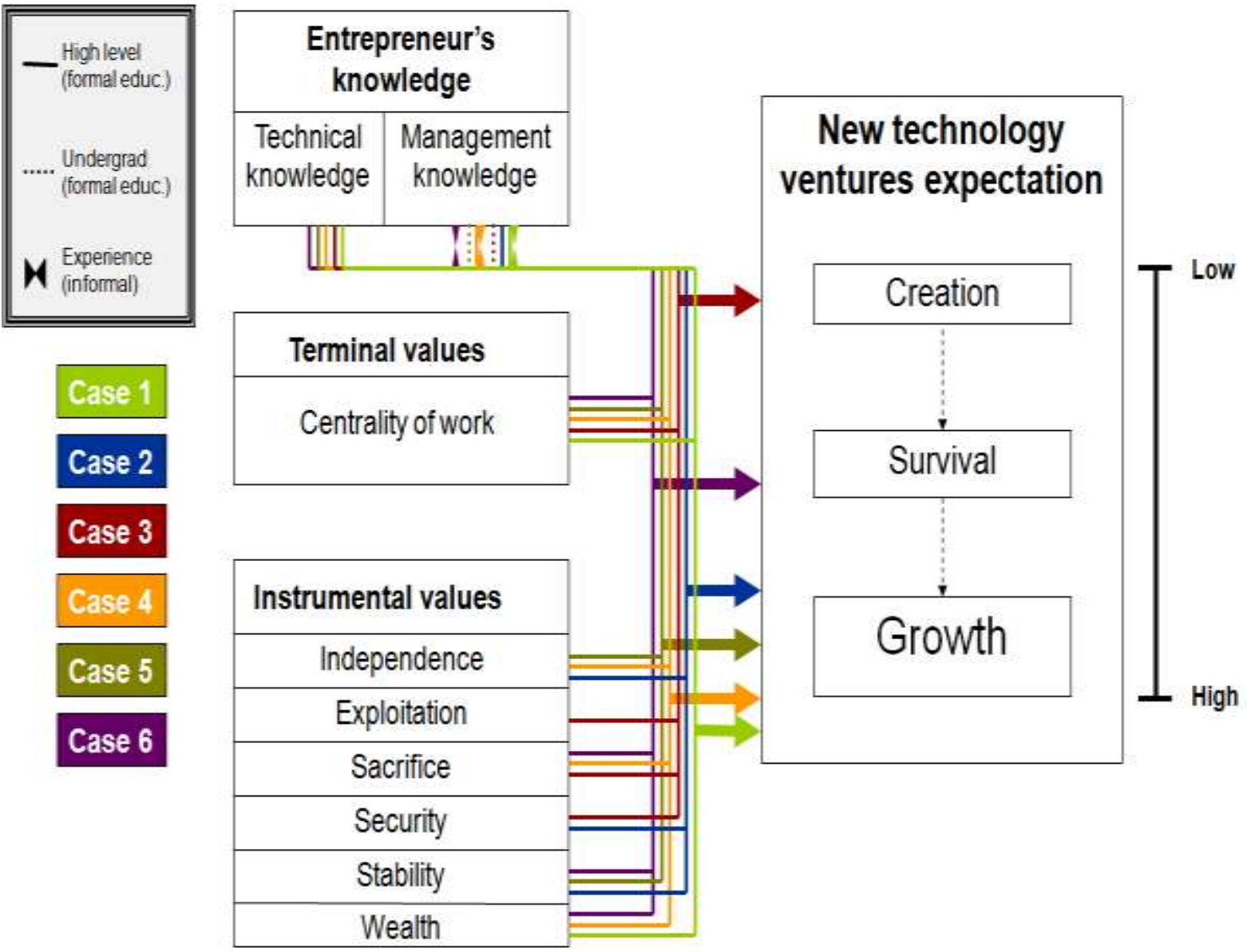

Source: own elaboration. 
Figure 5. Influence of entrepreneurs' knowledge and values on growth expectations
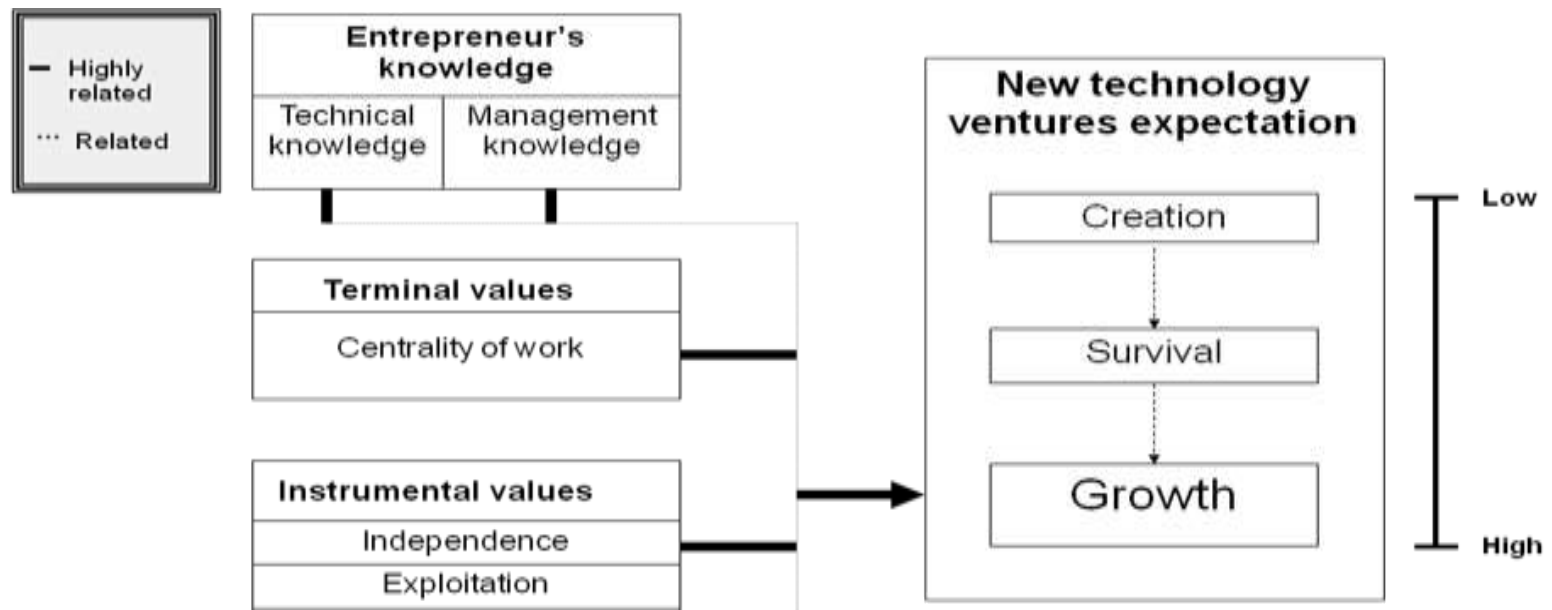

\begin{tabular}{|c|}
\hline Instrumental values \\
\hline Independence \\
\hline Exploitation \\
\hline Sacrifice \\
\hline Security \\
\hline Stability \\
\hline Wealth \\
\hline
\end{tabular}

Source: own elaboration.

According to the model proposed as a result of our findings, we finally conclude stating that both managerial and technical high levels of knowledge are related to higher growth expectations -proposition 1a and 1b-. This supports what Cheraghi, Zetti, and Schott (2014) state about the presence of knowledge as one of the key predictors of growth expectations.

In the same way, terminal value "centrality of work" is strongly related to high growth expectations -proposition 2-. This is also supported by Gorgievski, Moriano, and Bakker (2014) who demonstrated a positive relation between hard work (work engagement) and the pathway to growth and success.

Despite the findings published by Douglas (2103), who stated that growth intentions and independence intentions are driven by different cognitive aspects, in our research we found that instrumental values "independence" and "wealth" are highly related to higher growth expectations -propositions $3 \mathrm{a}$ and $3 \mathrm{c}-$. 
Regarding the rest of the instrumental values, "sacrifice" and "stability" were found to be partially related to a high expectation of growth $-3 b$ and $3 f-$, while instrumental values "exploitation" and "security" didn't show a significant relation to high growth expectations propositions $3 \mathrm{~d}$ and $3 \mathrm{e}-$.

Implications of this work contribute to further understanding the relationship between entrepreneurs' knowledge and their values in the expectations of companies in a sector with a key role in regional economic development. In addition, the use of these case studies allowed us to access interesting data to be processed and understand the way the entrepreneurs' personal values influence in new ventures management practices and performance. In accordance to Cheraghi, Zetti, and Schott (2014), results of this research prove that growth expectation derives from a variety of factors including knowledge and motivational beliefs. Moreover, these insights lead us to some recommendations for policy-makers. Nowadays, a lot of efforts and public budget is invested on new technology companies and, especially oriented to turn research funding at universities into real business. Besides the product and the market, it is important to look at the individual behind this new venture and to know if this person really wants to create a company or this is just a good way of continuing developing their technical tasks. The understanding of the individuals' values will help institutions to understand why some of them have a very fast growth and others are stagnated even if they have the same level of technical and managerial knowledge.

Limitations of this study are on one hand that only six cases were analyzed in an emerging sector with an enormous role in regional development; due to this, it is difficult to generalize the model proposed; on the other hand only personal values were taken into account for the analysis putting aside cultural and sector values. Future lines of research regarding this topic 
include analyses of a greater amount of cases, the inclusion of cultural and sector values for the analysis and exploring deeper the impact of each type of knowledge in firms' performance. Moreover, the study of the new ventures' real growth in a longitudinal analysis represents very interesting additional information to contribute to this study.

\section{References}

Almor, Tamar, and Miri Lerner. 2002. "Relationships among strategic capabilities and the performance of women-owned small ventures.” Journal of Small Business Management 40 (2): $109-125$

Alvarez, Isabel, and Raquel Marin. 2013. "FDI and Technology as Levering Factors of Competitiveness in Developing Countries." Journal of International Management 19: 232-246.

Amit, Raphael, Kenneth MacCrimmon, John Oesch, and Charlene Zietsma. 2000. "Does money matter? : Wealth attainment as the motive for initiating growth-orientated technology ventures." Journal of Business Venturing 16: 119-143.

Arenius, Pia, and Maria Minniti. 2005. "Perceptual variables and nascent entrepreneurship." Small Business Economics 24 (1): 233-247.

Arthurs, Jonathan, and Lowell Busenitz. 2006. "Dynamic capabilities and venture performance: The effects of venture capitalists." Journal of Business Venturing 21 (2): 195-215.

Astebro, Thomas, and Irwin Bernhardt. 2005. “The Winner's curse of human capital.” Small Business Economics 24 (1): 63-78.

Audretsch, David. 1995. Innovation and industry evolution. Cambridge MA.: MIT Press.

Backes-Gelner, Uschi, and Arndt Werner. 2007. "Entrepreneurial signaling via education: A success factor in innovative start-ups." Small Business Economics 29 (2): 173-190.

Barney, Jay. 2001. "Resource-based theories of competitive advantage: A ten year retrospective on the resource-based view." Journal of Management 27(4): 643-650.

Biggiero, Lucio. 2006. "Industrial and knowledge relocation strategies under the challenges of globalization and digitalization: The move of small and medium enterprises among territorial systems." Entrepreneurship and Regional Development 18: 443-471.

Breznitz, Dan, and Mollie Taylor. 2014. "The communal roots of entrepreneurial-technological growth social fragmentation and stagnation: reflection on Atlanta's technology cluster." Entrepreneurship and Regional Development 26: 3-4. 
Campos, Alejandro, and Esther Hormiga. 2010 "The state of the art of knowledge research in entrepreneurship: A ten-year literature review." Paper presented at the RENT XXIV Research in Entrepreneurship and Small Business: The Entrepreneurial Process in a Changing Economy. Maastricht, the Netherlands, November 18-19.

Cassar, Gavin. 2007. "Money, money, money? A longitudinal investigation of entrepreneur career reasons, growth preferences and achieved growth." Entrepreneurship and Regional Development 19 (1): 89-107.

Cheraghi, Maryam, Setti Zakia, and Thomas Schott. 2014. "Growth-expectations among women entrepreneurs: embedded in networks and culture in Algeria, Morocco, Tunisia and in Belgium and France." International Journal of Entrepreneurship and Small Business 23: 1-2.

Chrisman, James, and McMullan. 2004. "Outsider assistance as a knowledge resource for new venture survival." Journal of Small Business Management 42 (3): 229-244.

Collins-Dodd, Irene Colleen, M. Gordon, and Carolyne Smart. 2004. "Further evidence on the role of gender in financial performance.” Journal of Small Business Management 42 (4): 395-417.

Collinson, Simon. 2000. "Knowlege networks for innovation in small Scottish software firms." Entrepreneurship \& Regional Development 12 (3): 217-244.

Colombelli, Alessandra, Jackie Krafft, and Francesco Quatraro. 2014. "High Growth Firms and Technological Knowledge: Do gazelles follow exploration or exploitation strategies?" Industrial and Corporate Change 23 (1): 261-291.

Colombo, Massimo, and Luca Grilli. 2010. "On growth drivers of high-tech start-ups: Exploring the role of founders' human capital and venture capital." Journal of Business Venturing 25: 610626.

Conner, Kathleen, and C.K. Prahalad. 1996. "A resource-based theory of the firm: Knowledge versus opportunism." Organization Science 7 (5): 477-501.

Cooper, Arnold C., F. Javier Gimeno-Gascon, and Carolyn Y. Woo. 1994. "Initial human and financial capital as predictors of new venture performance." Journal of business venturing 9 (5): 371-395.

Corbett, Andrew. 2007. "Learning asymmetries and the discovery of entrepreneurial opportunities." Journal of Business Venturing 22: 97-118.

Cowling, Marc, and Mark Taylor. 2001. "Entrepreneurial women and men: Two different species?" Small Business Economics 16 (2): 167-175.

De Clercq, Dirk, and Arenius Pia. 2006. "The role of knowledge in business start-up activity." International Small Business Journal 24 (4): 339-358. 
De Mol Eva, Svetlana Khapova, and Tom Elfring. 2015. "Entrepreneurial Team Cognition: A Review." International Journal of Management Reviews 17: 232-255.

Deeds, David, Dona De Carolis, and Joseph Coombs. 2000. "Dynamic capabilities and new product development in high technology ventures: An empirical analysis of new biotechnology firms." Journal of Business Venturing 2: 211-229.

Dimov, Dimo, and Dean Shepherd. 2005. "Human capital theory and venture capital firms: Exploring “home runs"' and "strike outs"., Journal of Business Venturing 20 (1): 1-21.

Douglas, Evan. 2013. "Reconstructing entrepreneurial intentions to identify predisposition for growth.” Journal of Business Venturing 28 (5): 633- 651.

Dutta, Dev, and Thornhill Stewart. 2008. "The evolution of growth intentions: Toward a cognitionbased model." Journal of Business Venturing 23 (2): 307-332.

Eccles, Jacquelynne S., and Allan Wigfield. 2002. "Motivational beliefs, values, and goals." Annual review of psychology 53 (1): 109-132.

Edelman, Linda, Candida Brush, Tatiana Manalova, and Patricia Greene. 2010. "Start-up motivations and growth intentions of minority nascent entrepreneurs." Journal of Small Business Management 48 (2): 174-196.

Eisenhart, Kathleen. 1989. "Building theories from case study research." Academy of Management Review 14 (4): 532-551.

Elizur, Dov, and Abraham Sagie. 1999. "Facets of personal values: A structural analysis of life and work values." Applied Psychology 48 (1): 73-87.

Evans, Amanda, Carney Jamie, and Wilkinson Morgan. 2013. "Work-Life Balance for Men: Counseling Implications.” Journal of Counseling and Development 91 (4): 436-441.

Feather, Norman T. 1988. "Values, valences, and course enrollment: Testing the role of personal values within an expectancy-valence framework." Journal of educational psychology 80 (3): 381.

Feather, Norman T. 1995. "Values, valences, and choice: The influences of values on the perceived attractiveness and choice of alternatives." Journal of personality and social psychology 68 (6): 1135 .

Ferrante, Francesco. 2005. "Revealing entrepreneurial talent.” Small Business Economics 25 (2): 159174.

Friar, Jonh, and Meyer Marc. 2003. "Entrepreneurship and start-ups in the Boston region: Factors differentiating high-growth ventures from micro-ventures." Small Business Economics 21 (2): 145-152.

García, Salvador, and Dolan Shimon. 2003. La dirección por valores. Madrid: McGraw-Hill. 
Gatewood, Elizabeth J., Kelly G. Shaver, and William B. Gartner. 1995. "A longitudinal study of cognitive factors influencing start-up behaviors and success at venture creation." Journal of business venturing 10 (5): 371-391.

Gorgievski, Marjan, Juan Antonio Moriano, and Arnold Bakker. 2014. "Relating work engagement and workaholism to entrepreneurial performance." Journal of Managerial Psychology 29 (2): 106-121.

Grant, Robert. 1991. "The resource-based theory of competitive advantage: Implications for strategy formulation." California Management Review 33 (3): 114-136.

Hindle, Kevin, and Cutting Neil. 2002. "Can applied entrepreneurship education enhance job satisfaction and financial performance? An empirical investigation in the Australian pharmacy profession." Journal of Small Business Management 40 (2): 162-167.

Honig, Benson. 2001. "Human capital and structural upheaval: A study of manufacturing firms in the west bank.” Journal of Business Venturing 16 (5): 575-594.

Hyytinen, Ari, and Ilmakunnas Pekka. 2007. "Entrepreneurial aspirations: Another form of job search?" Small Business Economics 29 (1): 63-80.

Junkunc, Marc. 2007. "Managing radical innovation: The importance of specialized knowledge in the biotech revolution.” Journal of Business Venturing 22 (3): 388-411.

Keil, Mark, Koo Lee, and Hyung Tianjie Deng. 2013. "Understanding the most critical skills for managing IT projects: A Delphi study of IT project managers." Information and Management 50: 398-414.

Kim, Phillip, Aldrich Howard, and Lisa Keister. 2006. "The impact of financial, human, and cultural capital on entrepreneurial entry in the United States." Small Business Economics 27 (1): 5-22.

Koellinger, Phillip, and Maria Minniti. 2006. "Not for lack of trying: American entrepreneurship in black and white." Small Business Economics 27 (1): 59-79.

Kundu, Sumit, and Jerome Katz. 2003. "Born-international SMEs: BI-level impacts of resources and intentions." Small Business Economics 20 (1): 25-47.

Lee, Sang Suk, and Jerome S. Osteryoung. 2004. "A comparison of critical success factors for effective operations of university business incubators in the United States and Korea." Journal of Small Business Management 42 (4): 418-426.

Lin, Yini, and Lei-Yu Wu. 2014. "Exploring the role of dynamic capabilities in firm performance under the resource-based view framework." Journal of Business Research 67 (3): 407-413.

Lin, Zhengxi, Picot Garnett, and Janice Compton. 2000. "The entry and exit dynamics of selfemployment in canada." Small Business Economics 15 (1): 105-125. 
Love, James, and Stephen Roper. 2015. "SME innovation, exporting and growth: A review of existing evidence." International Small Business Journal 33 (1): 28-48.

Lyles, Marjorie. 2014. “Organizational Learning, knowledge creation, problem formulation and innovation in messy problems." European Management Journal 32 (1): 132-136.

Macdonald, Stuart, Assimakopoulos Dimitris, and Anderson Pat. 2007. "Education and training for innovation in SMEs: A tale of exploitation.” International Small Business Journal 25 (1): 7797.

Marvel, Matthew, and George T. Lumpkin. 2007. "Technology entrepreneurs' human capital and its effects on innovation radicalness." Entrepreneurship: Theory and Practice 31 (6): 807.

Mitra, Jay. 2012. Entrepreneurship, Innovation and Regional Development. New York, NY: Routledge Editors.

Moreno Luzón, Maria, and Begoña Lloria. 2008. "The role of non-structural and informal mechanisms of integration and coordination as forces in knowledge creation." British Journal of Management 19: 250-276.

Mueller, Pamela. 2006. "Entrepreneurship in the region: Breeding ground for nascent entrepreneurs?" Small Business Economics 27 (1): 41-58.

Nziramasanga, Mudziviri, and Lee Minsoo. 2001. "Duration of self-employment in developing countries: Evidence from small enterprises in Zimbabwe." Small Business Economics 17 (2): 239-253.

Oakey, Raymund. 2003. "Technical entrepreneurship in high technology small firms: Some observations on the implications for management." Technovation 23 (8): 679-688.

O'Gorman, Colm, and Kautonen Mika. 2004. "Policies to promote new knowledge-intensive industrial agglomerations." Entrepreneurship and Regional Development 16: 459-479.

Palacios, Daniel, Ignacio Gil, and Fernando Garrigos. 2009. "The impact of knowledge management on innovation and entrepreneurship in the biotechnology and telecommunications industries." Small Business Economics 32 (3): 291-301.

Parker, Simon. 2006. "Learning about the unknown: How fast do entrepreneurs adjust their beliefs?" Journal of Business Venturing 21 (1): 1-26.

Peña, Iñaki. 2002. "Knowledge networks as part of an integrated knowledge management approach." Journal of Knowledge Management 6 (5): 469-478.

Peña, Inaki. 2004. "Business incubation centers and new firm growth in the basque country." Small Business Economics 22 (2): 223-236. 
Poon, June, Ainuddin Raja Azimah, and Junit Sa'Odah Haji. 2006. "Effects of self-concept traits and entrepreneurial orientation on firm performance.” International Small Business Journal 24 (1): $61-84$

Prodan, Igor, and Drnovsek Mateja. 2010. "Conceptualizing academic-entrepreneurial intentions: An empirical test." Technovation 30 (5-6): 332-347.

Rodríguez, Blanca María Martins. 2003. "El modelo general de valoración de startups (SGVM): Un enfoque del capital intelectual." Revista de economía y empresa 19 (48): 87-102.

Roe, Robert, and Esther Peter. 1999. "Values and work: Empirical findings and theoretical perspective." Applied Psychology: An International Review 48 (1): 1-21.

Rokeach, Milton. 1973. The nature of human values. New York: Free Press.

Roxas, Banjo. 2013. "Effects of entrepreneurial knowledge on entrepreneurial intentions: a longitudinal study of selected South-east Asian business students." Journal of Education and Work 27 (4): 432-453.

Schildt, Henri, Markku Maula, and Thomas Keil. 2005. "Explorative and exploitative learning from external corporate ventures." Entrepreneurship: Theory and Practice 29 (4): 493-515.

Schwartz, Shalom. 1999. "Cultural value differences: Some implications for work." Applied Psychology: An International Review 48 (1): 23-48.

Seawright, Kristie, Mitchell Ronald, and Smith Brock. 2008. "Comparative entrepreneurial cognitions and lagging Russian new venture formation: A tale of two countries." Journal of Small Business Management 46 (4): 512-535.

Sharder, Rod, and Siegel Donald. 2007. "Assessing the relationship between human capital and firm performance: Evidence from technology-based new ventures." Entrepreneurship: Theory and Practice 31 (6): 893-910.

Thomas, Kathleen. 2009. "The impact of education histories on the decision to become self-employed: A study of young, aspiring, minority business owners." Small Business Economics 33 (4): 455466.

Thompson, Piers, Dylan Jones-Evans, and Caleb Kwong. 2010. "Education and entrepreneurial activity: A comparison of white and South Asian men." International Small Business Journal 28 (2): $147-164$

Timmons, Jeffry A. 1990. New business opportunities: getting to the right place at the right time. Brick House Pub Co.

Ucbasaran, Deniz, Paul Westhead, and Mike Wright. 2008. "Opportunity identification and pursuit: Does an entrepreneur's human capital matter?” Small Business Economics 30 (2): 153-173. 
Van Geenhuizen, Marina. 2008. "Knowledge networks of young innovators in the urban economy: Biotechnology as a case study." Entrepreneurship and Regional Development 20: 161-183.

Van Gelderen, Marco, Roy Thurik, and Niels Bosma. 2005. "Success and risk factors in the prestartup phase." Small Business Economics 24 (3): 365-380.

Van Gelderen, Marco, Lidewey Van de Sluis, and Paul Jansen. 2005. "Learning opportunities and learning behaviours of small business starters: Relations with goal achievement, skill development and satisfaction." Small Business Economics 25 (1): 97-108.

Van Praag, C. Mirjam, and Jan S. Cramer. 2001 "The roots of entrepreneurship and labour demand: Individual ability and low risk aversion." Economica 68 (269): 45-62.

Van Praag, Mirjam. 2003. "Business survival and success of young small business owners." Small Business Economics 21 (1): 1-17.

Vinogradov, Evgueni, and Lars Kolvereid. 2007. "Cultural background, human capital and selfemployment rates among immigrants in Norway." Entrepreneurship and Regional Development 19: 359-376.

Watson, Warren, Wayne Stewart Jr., and Anat BarNir. 2003. "The effects of human capital, organizational demography, and interpersonal processes on venture partner perceptions of firm profit and growth.” Journal of Business Venturing 18 (2): 145-164.

Wernerfelt, Birger. 1984. “A resource-based view of the firm.” Strategic Management Journal 5 (2): 171-180.

West III, Page, and Noel Terry. 2009. "The impact of knowledge resources on new venture performance.” Journal of Small Business Management 47 (1): 1-22.

West III, Page. 2007. "Collective cognition: When entrepreneurial teams, not individuals, make decisions." Entrepreneurship: Theory and Practice 31 (1): 77-104.

Wiklund, Johan, and Shepherd Dean. 2003. "Aspiring for, and achieving growth: The moderating role of resources and opportunities." Journal of Management Studies 40 (8): 1919-1941.

Wiklund, Johan, Davidsson Per, and Frederic Delmar. 2003. "What do they think and feel about growth? an expectancy-value approach to small business managers' attitudes toward growth.” Entrepreneurship: Theory and Practice 27: 247-270.

Williams, Donald. 2004. "Youth self employment: Its nature and consequences." Small Business Economics 23 (3): 323-336.

Williams, Jasmine, and Ian Chaston. 2004. "Links between the linguistic ability and international experience of export managers and their export marketing intelligence behaviour." International Small Business Journal 22 (5): 463-486.

Williams, Robin Murphy. 1970. American society: A sociological interpretation. New York: Knopf. 


\section{Journal of Evolutionary Studies in Business}

Yin, Robert K. 1998. "The abridged version of case study research. Design and method." In Handbook of Applied Social Research Method, edyted by Leonard Bickman and Debra J. Rog, 229. London: SAGE Publications.

Yin, Robert K. 1989. Case study research. Design and methods. Newbury Park, CA: SAGE Publications.

Zacharakis, Andrew.1997. "Entrepreneurial entry into foreign markets: A transaction cost perspective." Entrepreneurship: Theory and Practice 21 (3): 23-40.

Zarutskie, Rebecca. 2010. "The role of top management team human capital in venture capital markets: Evidence from first-time funds.” Journal of Business Venturing 25 (2): 155-172.

This is an Open Access article distributed under the terms of the Creative Commons Attribution-Non-Commercial-No Derivatives License (http://creativecommons.org/licenses/by-nc-nd/4.0/), which permits non-comercial re-use and distribution, provided the original work is properly cited, and is not altered or transformed in any way. 